\title{
Karanie uczestników wydarzeń marcowych z 1968 r. przez kolegia karno-administracyjne
}

\author{
Abstract \\ The Penalization of the Participants of the March 1968 Events by Criminal- \\ Administrative Colleges
}

In March 1968, in the streets of Warsaw, Polish students protested against the communist authorities' restriction of freedom of cultural and artistic activity. Demonstrations taking place during the so-called March events were brutally pacified by the militia, and participants in the events were charged with breach of the peace. When considering cases of their offenses, the penal-administrative colleges imposed severe basic arrest penalties and high fines, which were usually immediately convertible into alternative arrest. The penalties isolating the offender from society were imposed in an accelerated procedure without any guarantee of defence of the rights of the accused. This practice of the colleges' severe punishment of participants in social protests, which was initiated during the March events of 1968, would be repeated during successive political crises of the 1970s and 1980s.

Keywords: Boards adjudicating petty offences, March events, Polish People's Republic, Ministry of Home Affairs

Słowa kluczowe: kolegia karno-administracyjne, wydarzenia marcowe, Polska Ludowa, Ministerstwo Spraw Wewnętrznych

\section{Wstęp}

Historyk prawa zajmujący się okresem Polski Ludowej w pierwszej kolejności skieruje swoje kroki do Archiwum Akt Nowych w Warszawie (AAN), gdzie bez wątpienia znajduje się największy zasób materiałów źródłowych pochodzących z okresu powojennego. Jednakże w zasobach AAN nie odnajdziemy dokumentów stworzonych przez wszechwładny resort spraw wewnętrznych, które po upadku systemu komunistycznego 
zostały przekazane do Instytutu Pamięci Narodowej (IPN). Materiały uzyskane w wyniku kwerendy przeprowadzonej w centrali IPN w Warszawie oraz białostockim oddziale Instytutu wykorzystałem w badaniach nad prawem wykroczeń Polski Ludowej. Wyniki tych badań przedstawiłem w referacie zaprezentowanym podczas zorganizowanego w dniu 19 września 2019 r. przez krakowskie środowisko historyków prawa sympozjum pt. „Łączą nas źródła”. Do wygłoszonego w Krakowie referatu nawiązuje niniejszy artykuł, gdyż porusza jeden z najciekawszych aspektów praktyki orzecznictwa w sprawach o wykroczenia w Polsce Ludowej, jakim było represjonowanie osób publicznie wyrażających swój sprzeciw wobec polityki władz komunistycznych. Polityczne uwarunkowania tego orzecznictwa zostaną przedstawione na przykładzie sporządzonych przez Departament Społeczno-Administracyjny Ministerstwa Spraw Wewnętrznych (DSA MSW) raportów z przebiegu rozpraw karno-administracyjnych) przeciwko uczestnikom tak zwanych wydarzeń marcowych z 1968 r. Przed kolegiami karno-administracyjnymi (k-a) odpowiadały wówczas osoby zatrzymane w związku z udziałem w protestach studenckich przeciwko ograniczaniu przez władze swobody działalności kulturalnej, które w dniach 8-11 marca miały miejsce na terenie Uniwersytetu Warszawskiego (UW) oraz na ulicach śródmieścia Warszawy. Represja k-a dosięgła także demonstrujących w ramach solidarności ze protestującymi na ulicach Warszawy studentów uczelni lubelskich, natomiast w Krakowie aparat administracji spraw wewnętrznych został postawiony w stan gotowości w oczekiwaniu na dalszy rozwój wypadków.

\section{Charakterystyka modelu orzecznictwa karno-administracyjnego Polski Ludowej}

Orzecznictwo w sprawach o wykroczenia, które do momentu wejścia w życie z początkiem 1972 r. ustaw kodyfikujących materialne, procesowe i ustrojowe prawo wykroczeń ${ }^{1}$ było określane terminem orzecznictwo karno-administracyjne ${ }^{2}$, zostało przekazane do kompetencji Ministra Spraw Wewnętrznych (MSW) wraz reaktywacją tego urzędu w grudniu 1954 r. ${ }^{3}$ Do końca okresu komunistycznego MSW sprawował zwierzchni nadzór nad orzecznictwem k-a, początkowo przy pomocy Biura Nadzoru nad Orzecznictwem k-a ${ }^{4}$. W wyniku reorganizacji MSW w drugim kwartale 1958 r. zadania w tym zakresie powierzono nowo utworzonemu Wydziałowi Karno-Administracyjnemu.

1 Składały się na nią trzy ustawy z dnia 20 maja 1971 r.: Kodeks wykroczeń (Dz.U. $1971 \mathrm{nr} 12$ poz. 114); Kodeks postępowania w sprawach o wykroczenia (Dz.U. $1971 \mathrm{nr} 12$ poz. 116); oraz Ustawa o ustroju kolegiów do spraw wykroczeń (Dz.U. $1971 \mathrm{nr} 12$ poz. 118).

2 Łysko, Prace nad kodyfikacja, 307.

3 Zwierzchni nadzór nad orzecznictwem k-a został przekazany Ministrowi Spraw Wewnętrznych przez Prezesa Rady Ministrów na mocy dekretu z dnia 7 grudnia 1954 r. o naczelnych organach administracji państwowej w zakresie spraw wewnętrznych i bezpieczeństwa publicznego (Dz.U. $1954 \mathrm{nr} 54$ poz. 269).

4 Notatka Biura Nadzoru MSW z dnia 7 października 1955 r. w sprawie działalności Biura Nadzoru nad Orzecznictwem Karno-Administracyjnym, Instytut Pamięci Narodowej w Warszawie, Biuro Udostępniania i Archiwizacji Dokumentów, zespół akt Ministerstwo Spraw Wewnętrznych I, sygn. 524, s. 16 (IPN BU 1584/524, 16).

Artykuły - Articles 
Wydział ten funkcjonował w strukturach Departamentu Społeczno-Administracyjnego (DSA) $\mathrm{MSW}^{5}$, którego pierwszym dyrektorem został dotychczasowy kierownik Biura Nadzoru MSW - współodpowiedzialny za zbrodnie sądowe okresu stalinowskiego Henryk Chmielewski. Wykonywany przez MSW zwierzchni nadzór przejawiał się między innymi w prawie wydawania wytycznych dla polityki karnej w sprawach o wykroczenia. Wytyczne określały zasady karania, czyli zasady wymierzania kar za określone rodzaje wykroczeń. Wprawdzie posiadały charakter ogólny i nie mogły wskazywać sposobu rozstrzygnięcia konkretnej sprawy, lecz w praktyce orzecznictwa wytycznym przyznawano pierwszeństwo przed regulacjami ustawowymi regulującymi zasady wymiaru kar za wykroczenia ${ }^{6}$.

Bezpośredni nadzór nad orzecznictwem k-a sprawowały terenowe organy administracji państwowej - prezydia rad narodowych, które od 1950 r. wykonywały także zadania z zakresu administracji spraw wewnętrznych. Prezydia posiadały prawo udzielania ogólnych wytycznych dla orzecznictwa k-a na terenie ich działania oraz kontroli ich wykonania przez organy orzekające ${ }^{7}$. Terenowy aparat administracji spraw wewnętrznych, wykonywał zadania związane z obsługą organizacyjno-techniczną oraz prawną kolegiów k-a ${ }^{8}$. Po reformie systemu rad narodowych z $1958 \mathrm{r}$. aparat ten tworzyły wojewódzkie urzędy spraw wewnętrznych oraz powiatowe wydziały spraw wewnętrznych ${ }^{9}$. Zależność instytucjonalna organów orzekających od terenowego aparatu spraw wewnętrznych prowadziła do całkowitego ich podporządkowania bieżącym kierunkom polityki resortu spraw wewnętrznych.

${ }^{5}$ Notatka z dnia 28 czerwca 1958 r. w sprawie zakresu działania i struktury Departamentu Społeczno-Administracyjnego Ministerstwa Spraw Wewnętrznych, IPN BU MSW 1585/1919, s. 4. Zarządzenie Ministra Spraw Wewnętrznych z dnia 28 czerwca 1958 r. w sprawie zakresu działania Departamentu Społeczno-Administracyjnego Ministerstwa Spraw Wewnętrznych (Dz.U. MSW nr 23 poz. 72) z dnia 10 lipca 1958 r., IPN BU MSW 1585/1919, 4.

6 Łysko, „Kształtowanie polityki karnej”, 171-3.

7 W przypadku braku podstawy prawnej lub uznania, iż wydane orzeczenie było „oczywiście niesłuszne" prezydium rady narodowej mogło uchylić prawomocne orzeczenie działającego przy niej kolegium oraz kolegiów funkcjonujących przy prezydiach rad narodowych niższego szczebla podziału terytorialnego kraju. Lewiński, „Kształtowanie stosowanej przez kolegia”, 3.

8 Początkowo zadania związane z obsługą organizacyjno-prawną orzecznictwa w sprawach o wykroczenia wykonywały komórki organizacyjne terenowych organów administracji - prezydiów rad narodowych, które od marca $1950 \mathrm{r}$. posiadały status terenowych organów administracji ogólnej. Na szczeblu wojewódzkim zadania z zakresu administracji spraw wewnętrznych wykonywały wydziały społeczno-administracyjne, w ramach których problematyką orzecznictwa k-a zajmowały się referaty karno-administracyjne. W prezydiach powiatowych rad narodowych administracja spraw wewnętrznych znajdowała się w gestii referatów społeczno-administracyjnych, których wyznaczeni pracownicy w randze referentów k-a wykonywali zadania związane z orzecznictwem k-a. Łysko, „Aparat biurokratyczny”, 653-4. W wyniku reformy systemu rad narodowych ze stycznia $1958 \mathrm{r}$. wydziały prezydiów zyskały status samodzielnych organów administracji państwowej. Na szczeblu wojewódzkim powstały wojewódzkie urzędy spraw wewnętrznych, w ramach których orzecznictwem k-a zajmowały się oddziały karno-administracyjne. W powiatach funkcjonowały powiatowe (w miastach miejskie, a w miastach podzielonych na dzielnice - dzielnicowe) wydziały spraw wewnętrznych. Wydziały te wykonywały zadania związane z obsługą organów orzekających w sprawach o wykroczenia przy pomocy referatów karno-administracyjnych. W kolegiach I instancji funkcjonujących w dużych miastach i dzielnicach miast obsługą kolegiów zajmowały się wydziały karno-administracyjne. Leoński, „Kolegia w systemie", 20-1.

9 Ustawa z dnia 25 stycznia 1958 r. o radach narodowych (Dz.U. $1958 \mathrm{nr} 5$ poz. 16).

Artykuły - Articles 
Na mocy uchwalonej w apogeum polskiego stalinizmu Ustawy z dnia 15 grudnia 1951 r. o orzecznictwie karno-administracyjnym ${ }^{10}$ (u.k.a.) sprawy o wykroczenia rozstrzygały oparte na czynniku społecznym kolegia orzekające. Reprezentujący czynnik społeczny członkowie kolegiów orzekających byli wybierani przez terenowe organy władzy państwowej - rady narodowe - spośród kandydatów zgłaszanych przez organizacje społeczne i polityczne ludu pracującego oraz zakłady pracy ${ }^{11}$. Listy kandydatów na członków kolegiów sporządzały prezydia rad narodowych, dzięki czemu organy administracji państwowej w pełni kontrolowały proces obsady personalnej kolegiów orzekających. W myśl zasady kolegialności sprawy o wykroczenia rozpoznawały oparte na czynniku społecznym trzyosobowe składy orzekające, podczas gdy kierujący pracą kolegium przewodniczący $\mathrm{z}$ racji zasiadania $\mathrm{w}$ prezydium rady narodowej miał reprezentować czynnik urzędniczy ${ }^{12}$.

Kolegia orzekające funkcjonowały na wszystkich szczeblach podziału terytorialnego kraju. Zostały bowiem usytuowane przy prezydiach rad narodowych, które pełniły funkcję terenowych organów administracji. W miejsce sądowej kontroli orzecznictwa k-a przewidziano wzorowaną na procedurze administracyjnej instytucję odwołania do kolegium II instancji. W wyniku reformy systemowej z grudnia $1958 \mathrm{r}^{13}$ nastąpiło odejście od zasady obligatoryjnego tworzenia kolegiów w gromadach i osiedlach, gdyż kolegia te w praktyce nie podjęły szerszej działalności ${ }^{14}$. Podstawowym ogniwem w strukturze organizacyjnej uczyniono kolegia szczebla powiatowego, które jako organy I instancji funkcjonowały przy prezydiach powiatowych, dzielnicowych (w miastach podzielonych na dzielnice, m.in. w Warszawie) oraz rad narodowych większych miast. Organem II instancji wobec orzeczeń zapadłych na szczeblu powiatu było kolegium przy prezydium wojewódzkiej rady narodowej. Celem podniesienia niskiego poziomu funkcjonowania kolegiów reforma z grudnia 1958 r. wprowadziła wymóg posiadania wykształcenia prawniczego przez przewodniczącego kolegium oraz jego zastępców. Podobnym założeniem kierowano się, tworząc instytucję przewodniczących składów orzekających, którzy „w miarę możliwości” powinni byli rekrutować się spośród osób posiadających fachowe kwalifikacje ${ }^{15}$.

Reforma $\mathrm{z}$ grudnia $1958 \mathrm{r}$. określiła kolegialne organy orzekające $\mathrm{w}$ sprawach o wykroczenia mianem kolegiów karno-administracyjnych, przyznając im prawo stosowania kar wolnościowych w miejsce nieefektywnej kary pracy poprawczej ${ }^{16}$. Kara aresztu zasadniczego w wymiarze do trzech miesięcy mogła być orzekana w sprawach

10 Ustawa z 15 grudnia 1951 r. o orzecznictwie karno-administracyjnym (Dz.U. $1951 \mathrm{nr} 66$ poz. 454).

11 Łysko, „Socjalistyczna reforma orzecznictwa”, 322-3.

12 Siarkiewicz, „Kształtowanie się ustroju kolegiów”, 36.

13 Ustawą z dnia 2 grudnia 1958 r. o zmianie ustawy z dnia 15 grudnia 1951 r. o orzecznictwie karno-administracyjnym (Dz.U. $1958 \mathrm{nr} 77$ poz. 396).

14 Szerzej na ten temat Łysko, „Kształtowanie się ustroju kolegiów orzekających”, 269-73.

15 Na przewodniczących składów orzekających w pierwszej kolejności miały być powoływane osoby posiadające wykształcenie prawnicze, cechujące się znajomością zasad prawa karno-administracyjnego lub posiadające znajomość przynajmniej ,jednego z działów administracji państwowej”. Łysko, „Zasady obsady personalnej", 328.

16 Istota kary pracy poprawczej polegała na wykonywaniu pracy w uspołecznionym zakładzie pracy z potrąceniem $20 \%$ wynagrodzenia oraz innymi ograniczeniami, przy jednoczesnym podaniu faktu ukarania do wiadomości współtowarzyszy pracy. Osoby niezatrudnione w sektorze państwowym były kierowane do uspołecznionych zakładów pracy celem odbycia kary, przy czym orzeczenie o ukaraniu karą pracy popraw- 
o wykroczenia przybierające w praktyce postać czynów o charakterze chuligańskim oraz wykroczenia, do których znamion należała nietrzeźwość sprawcy ${ }^{17}$. Reforma z grudnia 1958 r. nie tylko potwierdziła uprawnienia przyznane kolegiom na mocy uchwalonej 22 maja 1958 r. ustawy antychuligańskiej ${ }^{18}$, lecz także dokonała znacznego poszerzenia katalogu wykroczeń zagrożonych karą aresztu zasadniczego o kolejną grupę czynów popełnionych „,Z motywów chuligańskich lub w sposób szczególnie złośliwy”19. Z racji przyznania kolegiom prawa stosowania środka karnego o charakterze izolacyjnym, częściowo przywrócono zniesioną przez reformę z grudnia 1951 r. instytucję zadania skierowania sprawy na drogę postępowania sądowego ${ }^{20}$.

Kontrolą sądową nie objęto natomiast orzeczeń kolegiów przewidujących zamianę nieuiszczonej w terminie grzywny na karę aresztu zastępczego. Znowelizowana w grudniu u.k.a. nie przewidywała żadnych ograniczeń w stosowaniu tej kary, podczas gdy wcześniejsza ustawa antychuligańska ograniczała to uprawnienie do enumeratywnie wymienionych czynów o charakterze chuligańskim. Po wejściu w życie nowelizacji u.k.a. z grudnia 1958 r. kolegia bardzo szeroko posługiwały się aresztem zastępczym²1, zwłaszcza w pozbawionym wszelkich gwarancji praw osoby obwinionej postępowaniu przyspieszonym. Przesłanką wprowadzenia przez MSW lub prezydium wojewódzkiej rady narodowej przyśpieszonego trybu postępowania było znaczne nasilenie występowania określonej grupy wykroczeń, którymi w praktyce były wykroczenia alkoholowo-chuligańskie lub czyny godzące w porządek i spokój publiczny ${ }^{22}$. Ten szczególny tryb postępowania przewidywał natychmiastowe doprowadzenie schwytanego przez funkcjonariuszy MO na gorącym uczynku sprawcy wykroczenia do kolegium. Zapadłe na rozprawie orzeczenia kolegium I instancji o ukaraniu aresztem zasadniczym podlegały natychmiastowemu wykonaniu ${ }^{23}$, podczas gdy w zwyczajnym trybie postępowania ukarany pozostawał na wolności do momentu rozpatrzenia odwołania przez sąd. Orzekając w trybie postępowania przyspieszonego, kolegium mogło także zarządzić natychmiastową wykonalność zastępczej kary aresztu. Przesłanką decyzji kolegium było stwier-

czej było podawane do publicznej wiadomości w ich miejscu zamieszkania. Łysko, „Ewolucja polskiego systemu", 175.

17 Były to następujące wykroczenia: zakłócanie spokoju publicznego, naruszenie przepisów porządkowych o zachowaniu się w miejscach publicznych, zakłócenie spoczynku nocnego, dopuszczenia się nieobyczajnego wybryku oraz używania słów nieprzyzwoitych. Areszt mógł być także orzeczony za zakłócanie porządku publicznego lub wywołanie zgorszenia publicznego w stanie nietrzeźwości. Bafia, O zaostrzeniu i przyśpieszeniu odpowiedzialności, 110 .

18 Ustawa z dnia 22 maja 1958 r. o zaostrzeniu odpowiedzialności karnej za chuligaństwo (Dz.U. 1958 nr 34 poz. 152). Szerzej na temat genezy tej ustawy, jej poszczególnych rozwiązaniach oraz praktyce orzecznictwa kolegiów w sprawach o wykroczenia chuligańskie zob. Łysko, „Problem chuligaństwa”, $179-202$.

19 Łysko, „Reforma prawa karno-administracyjnego”, 237.

20 Gubiński, „Ewolucja stosowanych przez kolegia środków”, 29-30.

21 Stosowanie kary grzywny z zamianą na areszt zastępczy w pierwszych latach po wejściu w życie nowelizacji u.k.a. z grudnia 1958 r. (Dz.U. 1958 nr 77 poz. 396) było bardzo szerokie, gdyż dotyczyło około 50-70\% orzeczonych grzywien. Celem ograniczenia skali tego zjawiska wydawane w pierwszej połowie lat sześćdziesiątych XX w. wytyczne MSW nakazywały kolegiom ograniczenie stosowania zastępczej kary aresztu do przypadków, gdy ukarany nie miał stałego miejsca zamieszkania lub stałego zatrudnienia. Gubiński, „Areszt zasadniczy i zastępczy”, 61.

22 Pacholarz, „Wykroczenia”, 22-3.

23 Stanowił o tym art. 40 ust. 3 znowelizowanej w duchu represyjnym 2 grudnia 1958 r. u.k.a. (Dz.U.1958 nr 77 poz. 396). 
dzenie, że ukarany nie będzie w stanie uiścić kary finansowej w terminie wskazanym W orzeczeniu ${ }^{24}$. W praktyce od ukaranego wysoką grzywną kolegium żądało jej wpłacenia natychmiast po zakończeniu rozprawy, co wiązało się z koniecznością posiadania przy sobie znacznej sumy pieniędzy. Ponieważ schwytani na gorącym uczynku sprawcy wykroczenia z reguły nie byli przygotowani na taką ewentualność, dlatego prosto z sali rozpraw trafiali do aresztu. W tym miejscu należy podkreślić, że w ramach tendencji do zaostrzenia „represyjności” systemu prawa k-a reforma z grudnia 1958 r. podwyższyła o połowę górną granicę kary grzywny. Rozwiązanie to doprowadziło do znacznego wzrostu dolegliwości materialnej kar orzekanych przez kolegia za najpoważniejsze wykroczenia. Znowelizowana ponownie w 1966 r. w związku z operacją przekazania niektórych występków jako wykroczeń do orzecznictwa k-a ${ }^{25}$ u.k.a. obowiązywała do momentu wejścia w życie z początkiem 1972 r. ustaw składających się na kompleksową kodyfikacjęprawa wykroczeń Polski Ludowej. Opierając się na regulacjach - dwukrotnie w okresie gomułkowskim poddanej gruntownej nowelizacji - u.k.a., kolegia k-a karały uczestników demonstracji studenckich, które przeszły do historii pod nazwą wydarzeń marcowych.

\section{Karanie uczestników protestów studenckich w dniu 8 marca 1968 r.}

Spośród zatrzymanych w pierwszym dniu protestów studenckich, określanych przez DSA MSW mianem „zajść”, najsurowiej potraktowano osoby uznane za ich organizatorów. Przeciwko „organizatorom zajść” zostały bowiem skierowane ,akty oskarżenia do sądu" ${ }^{26}$. Do odpowiedzialności k-a pociągnięto „uczestników zajść” na terenie UW i ulic śródmieścia Warszawy, sporządzając przeciwko nim wnioski o ukaranie za zakłócenie spokoju publicznego. Wykroczenie to było zagrożone karą aresztu do 2 miesięcy lub grzywną do 3000 złotych $^{27}$ przez obowiązujące w Polsce Ludowej do 1972 r. przedwojenne prawo o wykroczeniach ${ }^{28}$. Ogólnikowo sformułowana dyspozycja tego wykroczenia oprócz typowych zachowań polegających na wznoszeniu okrzyków, powodowaniu hałasu i podniesieniu alarmu przewidywała zakłócenie porządku publicznego ,innym wybrykiem". Brak ustawowej definicji tego pojęcia stwarzał organom ścigania możliwość kwalifikowania jako wybryków prowadzących do zakłócenia spokoju publicznego zachowań przybierających postać biernego udziału w demonstracjach studenckich, określanym przez DSA MSW mianem ,zbiegowiska publicznego" ${ }^{29}$.

24 „Karanie wykroczeń chuligańskich”, 3.

25 Ustawa z dnia 17 czerwca 1966 r. o przekazaniu niektórych drobnych przestępstwa jako wykroczeń do orzecznictwa karno-administracyjnego (Dz.U. 1966 nr 23 poz. 149).

26 Informacja $\mathrm{nr} 1 / 68 \mathrm{z}$ przebiegu rozpraw karno-administracyjnych przeciwko uczestnikom zajść na terenie Uniwersytetu Warszawskiego i niektórych ulic w dniu 8 marca 1968 r., IPN BU 1585/6657, 10.

27 W 1968 r. przeciętne miesięczne wynagrodzenie wynosiło 2106 złotych.

28 Art. 28 Rozporządzenia Prezydenta Rzeczypospolitej Polskiej z dnia 11 lipca 1932 r. Prawo o wykroczeniach (Dz.U. $1932 \mathrm{nr} 60$ poz. 572).

29 Informacja nr 1/68..., IPN BU 1585/6657, 11. 
Wzmocnieniu represji wobec osób biorących udział w wydarzeniach marcowych służyło traktowanie ich zachowań w kategoriach wykroczeń chuligańskich. Wynikało to z faktu, że obowiązująca ustawa antychuligańska zaliczała zakłócanie spokoju publicznego do grupy czynów, które „przeważnie i najczęściej mają charakter chuligański”. W przypadku stwierdzenia w działaniu sprawcy wykroczenia znamion chuligaństwa ustawa przewidywała zaostrzenie wymiaru kary. Zdaniem DSA MSW ustawodawca podkreślał w ten sposób potrzebę orzekanie surowych kar oscylujących wokół ,górnego wymiaru kary przewidzianej w ustawie za dany czyn" oraz zachęcał kolegia do stosowania kary aresztu zasadniczego ${ }^{30}$. Podyktowane względami prewencji generalnej surowe traktowanie uczestników wydarzeń marcowych przejawiało się także w zastosowaniu przyspieszonego trybu postępowania k-a w sprawach o wykroczenia popełnione przez osoby biorące udział w protestach studenckich. Przesłanką wprowadzenia na terenie Warszawy przyspieszonego trybu postępowania było znaczne nasilenie wykroczeń polegających na zakłóceniu porządku publicznego w związku z wydarzeniami marcowymi.

Pierwsze rozprawy przeciwko uczestnikom wydarzeń marcowych odbyły się 9 marca 1968 r. przed Kolegium Karno-Administracyjnym przy Prezydium Dzielnicowej Rady Narodowej Warszawa-Śródmieście. „Odpowiednio przygotowane” trzy składy orzekające kolegium rozpatrywało wnioski o ukaranie 10 osób zatrzymanych ${ }^{31} \mathrm{w}$ związku z udziałem w „zajściach”, które miały miejsce 8 marca na terenie Uniwersytetu Warszawskiego i na Krakowskim Przedmieściu. W ocenie DSA MSW reprezentujący czynnik społeczny członkowie składów orzekających prowadzili rozprawy „bardzo sprawnie”, gdyż starali się ,nie tylko oceniać czyny z punktu widzenia formalnego, ale i oddziaływać na obwinionych". Wysiłki podejmowane przez składy orzekające na rzecz obiektywnego rozpatrzenia wniosków o ukaranie miały znaleźć swój wyraz „w zróżnicowaniu kar i innych rozstrzygnięć”. Zajmujący się obsługą organizacyjno-prawną kolegium Wydział Karno-Administracyjny Prezydium DRN Warszawa-Śródmieście ${ }^{32}$ zapewnił udział w rozprawach funkcjonariuszy MO nie tylko w charakterze oskarżycieli publicznych, ale także świadków składających zeznania obciążające obwinionych.

W zależności od stopnia zaangażowania postawionych przed kolegium ,uczestników zajść" podzielono na cztery grupy. Najsurowiej potraktowano studentkę V roku Filozofii UW Irenę L., w której zachowaniu „dopatrzono się elementów organizatorskich”. Jej aktywna rola $\mathrm{w}$ organizacji protestów studenckich polegała na opracowaniu i odczytaniu podczas wiecu na dziedzińcu UW rezolucji wyrażającej protest „przeciwko usunięciu

30 Chmielewski, „Nowe poważne zadania”, 9.

31 Wśród zatrzymanych były dwie kobiety. Wiek dziewięciorga zatrzymanych wynosił od 19 do 24 lat, tylko jedna osoba miała 34 lata. Połowę z zatrzymanych (5 osób) stanowili studenci UW, dwie wykonywały zawód nauczyciela, jedna była uczniem Technikum Kolejowego, jedna pracownikiem umysłowym (laborantem), a jedna osoba nie miała wyuczonego zawodu. Dwoje zatrzymanych należało do Związku Młodzieży Socjalistycznej, a jeden z nich był członkiem PZPR. Informacja nr 1/68..., IPN BU 1585/6657, 10.

32 Funkcję Naczelnika Wydziału pełnił Jan Smereczański, którego zaangażowanie w przygotowanie rozpraw przeciwko uczestnikom wydarzeń marcowych oraz nadzór nad ich zgodnym z oczekiwaniami MSW przebiegiem zostanie doceniony przez kierownictwo resortu. Smereczański został później nagodzony przeniesieniem do pracy w DSA MSW, gdzie odgrywał rolę „,resortowego” eksperta w dziedzinie prawa wykroczeń. Był m.in. redaktorem naczelnym wydawanego przez DSA MSW kwartalnika „Zagadnienia Wykroczeń”, który stanowił kontynuację ukazującego się w latach 1958-1971 periodyku „Zagadnienia Karno-Administracyjne”. Przybysiak, „Od «Biuletynu» do «Zagadnień Wykroczeń»”, 24-25. 
2 studentów z uczelni ${ }^{33}$ i prowadzeniu postępowania przeciwko dalszym 8 studentom ${ }^{34}$ ". Rezolucje miała się zakończyć stwierdzeniem, że „na represje studenci odpowiedzą w sposób podobny jak studenci czechosłowaccy”. Została obwiniona o to, że „przemawiając do zbiegowiska, nawoływała krzykiem zebranych do pozostania, przez co zakłóciła spokój i porządek publiczny". Występujący w roli świadka funkcjonariusz MO złożył obciążające obwinioną studentkę zeznania, podkreślające jej „pierwszoplanową rolę w zajściach, przez wygłaszanie rezolucji i nawoływanie do dalszego manifestowania". Obwiniona w sposób ironiczny miała zakwestionować wiarygodność wypowiedzi świadka dotyczącej „udziału robotników w przywracaniu porządku”, gdyż zwróciła uwagę na fakt „bicia i kopania studentów przez cywili” ${ }^{35}$.

Chociaż zdaniem składu orzekającego kolegium materiał dowodowy w postaci zeznań funkcjonariusza MO przemawiał na niekorzyść obwinionej, to podczas rozprawy Irena L. nie przyznała się do zarzucanego jej czynu. Broniąc się przed postawionymi jej zarzutami, powoływała się zagwarantowaną $\mathrm{w}$ art. 71 konstytucji PRL wolność słowa oraz wolność zgromadzeń i wieców. Przyjęła linię obrony polegającą na zadawaniu pytań członkom składu orzekającego i prowadzeniu z nimi dyskusji. Taka postawa obwinionej została odebrana jako próba obniżenia powagi rozprawy i przesądziła o wymierzeniu najwyższej możliwej kary w postaci dwóch miesięcy aresztu. Zdaniem kolegium represja ekonomiczna w postaci kary grzywny „byłaby niewystarczająca z uwagi na charakter czynu i jego dużą szkodliwość społeczną, a także nasilenie złej woli”. Kolegium zarządziło natychmiastową wykonalność orzeczonej kary, wskutek czego ukarana Irena L. została bezpośrednio z sali rozpraw odprowadzona do aresztu ${ }^{36}$.

Drugą grupę zatrzymanych określano mianem „aktywnych uczestników zajść”, wśród których były trzy osoby: studenci UW - Katarzyna W. i Maciej W. oraz pracownik umysłowy (laborant) Jan K. Studiującej na I roku biologii Katarzynie W. (lat 19) zarzucono zakłócenie spokoju publicznego poprzez wznoszenie w stronę interweniujących na Krakowskim Przedmieściu milicjantów i członków „aktywu robotniczego” okrzyków „bandyci, gestapowcy, mordują młodzież”. Wzywając pomocy, spowodowała zbiegowisko z udziałem przechodniów, którzy pospieszyli jej na ratunek. Zeznający w charakterze świadków dwaj funkcjonariusze MO nie tylko potwierdzili fakt wznoszenia przez obwinioną do przechodniów okrzyków „biją młodzież, gestapo”, lecz także wskazali na prowokacyjne zachowanie polegające na głośnym śpiewaniu piosenek radzieckich. Podczas próby zatrzymania stawiała bierny opór, a wznoszone przez nią okrzyki miały skutkować próbą odbicia jej z rąk milicjantów przez przechodniów.

33 Chodziło o Adama Michnika i Henryka Szlajfera, którzy na wniosek ministra szkolnictwa wyższego Henryka Jabłońskiego zostali skreśleni z listy studentów UW za przekazywanie prasie francuskiej informacji o demonstracji studenckiej przeciwko zawieszeniu wystawiania sztuki Dziady, która miała miejsce po zakończeniu ostatniego spektaklu na scenie Teatru Narodowego w dniu 30 stycznia 1968 r. Marzec 1968, 12-3.

34 W odczytanej przez Irenę L. rezolucji studenci warszawskich uczelni domagali się umorzenia postępowania dyscyplinarnego przeciw Ewie Morawskiej, Marcie Petrusewicz, Józefowi Dajczgewandowi, Marianowi Dąbrowskiemu, Sławomirowi Kretkowskiemu, Janowi Lityńskiemu, Wiktorowi Nagórskiemu i Andrzejowi Polowczykowi, obwinionym o udział w demonstracji studenckiej po ostatnim przedstawieniu Dziadów. Eisler, Polski rok 1968. Warszawa: Instytut Pamięci Narodowej - Komisja Ścigania Zbrodni Przeciwko Narodowi Polskiemu, 2006, 234-235.

35 Informacja nr 1/68..., IPN BU 1585/6657, 11-2.

36 Ibidem, 12. 
Podczas rozprawy przed kolegium Katarzyna W. nie przyznała się do winy. Stwarzała wrażenie przygnębionej faktem pociągnięcia do odpowiedzialności k-a, była zdenerwowana, a chwilami nawet płakała. Twierdziła, że została uderzona pałką i dlatego uciekała z dziedzińca UW na ulicę. Wzywała pomocy przechodniów z obawy przed ponownym pobiciem. Pomimo okazanej przez obwinioną skruchy skład orzekający nie dał wiary jej wyjaśnieniom. Kolegium przyjęło jako okoliczność obciążającą fakt przebywania z własnej woli na Krakowskim Przedmieściu i wznoszenia tam szkalujących funkcjonariuszy MO okrzyków. Na niekorzyść obwinionej przemawiała także dostarczona kolegium przez Służbę Bezpieczeństwa informacja o utrzymywaniu przez jej rodzinę „ożywionych kontaktów z rodziną zamieszkałą za granicą, m.in. w Izraelu”. Zdaniem SB rodzina obwinionej reprezentowała poglądy syjonistyczne, czyli postawę potępianą przez czynniki oficjalne w ramach zainicjowanej po wojnie żydowsko-izraelskiej 1967 r. kampanii antysemickiej. W konsekwencji Katarzyna W. została ukarana grzywną w maksymalnej wysokości, podlegającą zamianie na dwa miesiące aresztu zastępczego. Kolegium zarządziło natychmiastową wykonalność orzeczonej kary, co wobec nieposiadania przez obwinioną przy sobie odpowiedniej kwoty na opłacenie grzywny skutkowało jej osadzeniem w areszcie ${ }^{37}$.

Kolejny z zatrzymanych ,aktywnych uczestników zajść” Ireneusz K. (lat 24) został obwiniony o zakłócanie w stanie nietrzeźwym porządku publicznego na Krakowskim Przedmieściu poprzez wznoszenie w kierunku interweniujących milicjantów okrzyków „gestapowcy, żandarmeria”. Podczas rozprawy zeznający w charakterze świadka funkcjonariusz MO nie tylko potwierdził fakt wznoszenia okrzyków, lecz także wskazał na stawianie przez obwinionego czynnego oporu podczas zatrzymania. Obwiniony zaprzeczył podnoszonym przeciwko niemu zarzutom, przyznając się jedynie do przebywania w stanie nietrzeźwości w miejscu publicznym. Próba podważania wiarygodności zeznań funkcjonariusza MO jedynie pogorszyła sytuację obwinionego, gdyż inny funkcjonariusz występujący w roli oskarżyciela publicznego złożył wniosek o zmianę kwalifikacji prawnej zarzucanego czynu. Obwiniony Ireneusz K. miał odpowiadać za naruszenie spokoju publicznego w stanie nietrzeźwości na podstawie stosownego przepisu ustawy o zwalczaniu alkoholizmu ${ }^{38}$, który dopuszczał wymierzenie surowszej kary grzywny ${ }^{39}$. Przychylając się do wniosku oskarżyciela publicznego, kolegium wymierzyło grzywnę w wysokości 3000 złotych podlegającą zamianie na 75 dni aresztu, aczkolwiek bez rygoru natychmiastowej wykonalności.

Trzeci z zatrzymanych pod zarzutem ,aktywnego udziału w zajściach” - student Maciej W. (lat 23) - odpowiadał za nieusłuchanie wezwania funkcjonariusza MO do rozejścia się. Zamiast opuścić zgromadzenie studenckie stawiał bierny opór, a po schronieniu się w jednym z budynków UW rzucił z okna doniczką w stronę interweniujących milicjantów. Zeznający w charakterze świadka funkcjonariusz MO nie tylko potwierdził

37 Ibidem, 12-3.

38 Ustawa z dnia 10 grudnia 1959 r. o zwalczaniu alkoholizmu (Dz.U. 1959 nr 69 poz. 434).

39 Chodziło o art. 27 ustawy, który penalizował zakłócenie porządku publicznego lub wywołanie zgorszenia w miejscu publicznym lub zakładzie pracy przez osobę znajdująca się w stanie nietrzeźwości. Wykroczenie to było zagrożone karami aresztu do 3 miesięcy lub grzywną w wymiarze do 4500 złotych, czyli do maksymalnej wysokości tych kar przewidzianych w u.k.a. Łysko, „Orzecznictwo karno-administracyjne”, 259.

Artykuły - Articles 
zarzuty zawarte we wniosku o ukaranie, lecz wskazał także na fakt wznoszenia przez obwinionego szkalujących milicjantów okrzyków. Na rozprawie obwiniony nie przyznał się do winy, chociaż wyjaśnił, że wiedział o mającym się odbyć na dziedzińcu UW wiecu i udał się na uczelnię w celu wzięcia w nim udziału. Przyjmując jako okoliczność obciążającą aroganckie zachowanie się obwinionego na rozprawie, kolegium wymierzyło grzywnę w maksymalnej przewidzianej przez u.k.a. wysokości - 3000 złotych podlegającą zamianie na 60 dni aresztu Chociaż kolegium orzekło natychmiastową wykonalność orzeczonej grzywny, to w wyniku jej opłacenia przez obecną na rozprawie siostrę ukaranego Maciej W. nie został osadzony w areszcie ${ }^{40}$.

Łagodniej kolegium potraktowano trzecią grupę obwinionych, określanych mianem „biernych uczestników zajść”. Osobom tym wprawdzie „udowodniono udział w zajściach i niedostatecznie szybkie reagowanie na wezwanie do rozejścia się", lecz okoliczności wskazywały na ich przypadkową obecność w miejscu protestów studenckich w dniu 8 marca 1968 r. Spośród czterech zatrzymanych „biernych uczestników zajść” grzywną w wysokości 1000 złotych z zamianą na 40 dni aresztu (bez rygoru natychmiastowej wykonalności) ukarano jedynie zajmującego się dorywczo fotografią 23-letniego Jeremiasza B. Oskarżyciel publiczny zarzucał mu, że ,nie podporządkował się wezwaniu funkcjonariusza MO do rozejścia się, uczestniczył w zbiegowisku, fotografując jego przebieg". Na rozprawie obwiniony potwierdził swoją obecność na terenie Uniwersytetu, gdzie miał się spotkać z koleżanką. Jednocześnie zaprzeczał, jakoby miał dopuścić się zakłócenia spokoju publicznego, gdyż wkrótce po wezwaniu milicji opuścił wiec studencki. Wcześniej jednak zdążył wykonać kilka zdjęć, sfotografował między innymi pobitego przez reprezentujących ,aktyw robotniczy” członków ORMO ${ }^{41}$ studenta. Podczas zatrzymania został odebrany obwinionemu aparat fotograficzny wraz z kliszą, na której znajdowały się negatywy zdjęć zrobionych podczas zamieszek na dziedzińcu UW. Ponieważ nie było jakichkolwiek przesłanek wskazujących na możliwość wywołania zrobionych zdjęć i przekazania ich osobom trzecim, oskarżyciel publiczny odstąpił od popierania wniosku o ukaranie na rozprawie, pozostawiając ocenę stanu faktycznego sprawy i końcowe rozstrzygnięcie członkom składu orzekającego kolegium ${ }^{42}$.

Trzech pozostałych ,biernych uczestników zajść” zostało ukaranych wyłącznie karą grzywny niepodlegającą zamianie na areszt zastępczy. Najsurowszą grzywnę - w wysokości 1000 złotych - kolegium orzekło w stosunku do zatrzymanego Wojciecha L., 26-letniego nauczyciela w Zasadniczej Szkole Zawodowej. Został obwiniony o to, że „brał udział w zbiegowisku, wznosząc głośno okrzyki, przez co zakłócił spokój i porządek publiczny". Podczas rozprawy nie przyznał się do winy, twierdząc, że w miejscu zamieszek ulicznych znalazł się przypadkowo. Zaprzeczył także, że wznosił okrzyki, chociaż występujący w roli świadka funkcjonariusz MO zeznał, że obwiniony w czasie interwencji milicji głośno krzyczał: „Co mi tu nie wolno stać?!”. W opinii członków składu orzekającego Wojciech L. „faktem doprowadzenia go na rozprawę był bardzo załamany", dlatego też został ukarany stosunkowo niewysoką grzywną bez zamiany na areszt zastępczy ${ }^{43}$.

40 Informacja nr 1/68..., IPN BU 1585/6657, 14.

41 ORMO - Ochotnicza Rezerwa Milicji Obywatelskiej.

42 Informacja nr 1/68..., IPN BU 1585/6657, 15.

43 Ibidem, 15-6. 
Dwukrotnie niższą grzywnę orzeczono w stosunku do 19-letniego studenta I roku ekonomii na UW Dariusza L., który uczestnicząc w zbiegowisku, zakłócał spokój publiczny poprzez wznoszenie głośnych okrzyków. Podczas rozprawy potwierdził jedynie, że przyłączył się do wiecu studenckiego pod wpływem „psychozy zebranego tłumu”. W przeciwieństwie do pozostałych rozpatrywanych 9 marca 1968 r. spraw oskarżyciel publiczny we wniosku o ukaranie nie wskazał świadka zdarzenia, wnosząc „o ukaranie według uznania Kolegium”. Kolegium przyjęło winę Dariusza L., opierając się na notatce służbowej sporządzonej przez funkcjonariuszy MO podczas zatrzymania, lecz wobec braku innych dowodów poprzestało na wymierzeniu stosunkowo niskiej grzywny w wymiarze 500 złotych. Uzasadniając przyjęte rozstrzygnięcie, wskazywano na występowanie okoliczności łagodzących, takich jak ,fakt przyznania się do winy, skrucha wyrażona na rozprawie, a także trudna sytuacja materialna obwinionego". Nie pobierał on stypendium i pozostawał na wyłącznym utrzymaniu matki, gdyż ojciec od kilku lat nie utrzymywał kontaktu z rodziną.

Łagodnie kolegium potraktowało także studenta Historii UW Eugeniusza T. (lat 21), który cierpiał na silne zaburzenia układu słuchowego i zmuszony był do posługiwania się aparatem słuchowym. Wprawdzie występujący jako świadek oskarżenia funkcjonariusz MO wskazywał na fakt czynnego udziału obwinionego w zbiegowisku polegający na wznoszeniu okrzyków oraz nieusłuchaniu wezwania do rozejścia się, lecz obwiniony nie przyznał się do winy. Twierdził, że gdy udawał się do stołówki studenckiej, został bez powodu kilkakrotnie uderzony pałką przez członka ORMO. W czasie rozprawy obwiniony zachowywał się spokojnie, okazał skruchę. Swoim kalectwem i defektem aparatu słuchowego wskutek wyczerpania baterii obwiniony wzbudził litość składu orzekającego. Przy wymiarze kary uwzględniono również fakt pozostawania obwinionego na wyłącznym utrzymaniu matki - rencistki należącej do Polskiej Zjednoczonej Partii Robotniczej (PZPR). Ostatecznie ,kolegium wymierzyło łagodną karę grzywny -300 złotych bez zamiany na areszt, biorąc pod uwagę trudne warunki materialne i kalectwo" 44 .

Ostatnią grupę obwinionych stanowili ci spośród „biernych uczestników zajść, w zachowaniu których kolegium stwierdziło „,brak natężenia złej woli”. W związku z tym przyjęto założenie, że „nie przyłącza się do ewentualnych dalszych ekscesów”. Pierwszym z nich był należący do Związku Młodzieży Socjalistycznej uczeń II klasy Technikum Kolejowego Ryszard K., obwiniony o „udział w zbiegowisku” i wznoszenie okrzyków. Obwiniony nie przyznał się do winy, twierdząc, że przebywał ze znajomymi w kawiarni znajdującej się obok miejsca ,zbiegowiska”. Kiedy na chwilę wyszedł na ulicę, żeby zorientować się w sytuacji, został jego zdaniem bez powodu zatrzymany. Na potwierdzenie swoich słów okazał numerek z szatni kawiarni, w której zostawił swój płaszcz. Ponieważ został doprowadzony na rozprawę bez płaszcza, stąd jego wyjaśnienia skład orzekający uznał za wiarygodne. Na korzyść obwinionego przemawiały także oczywiste rozbieżności pomiędzy zeznaniami występującego w roli świadka funkcjonariusza MO a notatką służbową sporządzoną podczas zatrzymania. Nie dysponując

44 Ibidem, 16. 
dowodami przemawiającymi za ukaraniem obwinionego, kolegium postanowiło odroczyć rozprawę w celu uzyskania opinii o jego osobie ${ }^{45}$.

Za wiarygodne kolegium uznało także wyjaśnienia złożone przez kolejnego z obwinionych, który w sposób przypadkowy znalazł się w miejscu protestów studenckich. Był to 34-letni nauczyciel z Ostrołęki Stanisław P., członek PZPR, mający na utrzymaniu żonę i dwójkę dzieci. Uczestniczył w odbywającej się w Warszawie dwudniowej konferencji Związku Nauczycielstwa Polskiego (ZNP), po zakończeniu której udał się do biblioteki UW celem zwrócenia wypożyczonych książek. Przechodząc przez dziedziniec UW, stał się mimowolnym uczestnikiem protestu studenckiego i został zatrzymany pod zarzutem udziału w zbiegowisku. Obwiniony przedłożył odpowiednie zaświadczenie potwierdzające udział w konferencji, a także książki, które zamierzał zwrócić w bibliotece UW. Ponieważ wskazany we wniosku o ukaranie jako świadek funkcjonariusz MO nie stawił się na rozprawie, kolegium ,wzięło pod uwagę prawdopodobieństwo wyjaśnień obwinionego" i odroczyło rozprawę. Uzasadniając podjętą decyzję, wskazywano także na fakt, że obwiniony pełnił funkcję wiceprezesa ZNP i był członkiem partii.

Odraczając rozprawy prowadzone przeciwko dwóm przypadkowym „uczestnikom zajść”, kolegium uzależniło wydanie „stosownego orzeczenia” od dalszego ich zachowania się po opuszczeniu sali rozpraw. W przypadku ponownego naruszenia spokoju publicznego zakładano wymierzenie kar grzywny podlegających zamianie na areszt zastępczy, z kolei powstrzymanie się obwinionych od dalszych naruszeń prawa miało skutkować odstąpieniem od wymierzania kary ${ }^{46}$.

\section{Rozprawy k-a przeciwko uczestnikom „zajść" w dniu 9 marca 1968 r.}

Kolejne rozprawy przeciwko uczestnikom protestów studenckich Kolegium Karno-Administracyjne przy Prezydium DRN Warszawa-Śródmieście wyznaczyło na dzień 11 marca. Przed kolegium odpowiadało 15 osób $^{47}$ (w tym 2 kobiety) zatrzymanych przez MO pod zarzutem zakłócenia spokoju i porządku publicznego podczas demonstracji ulicznych w dniu 9 marca 1968 r. Posługując się argumentem w postaci „rozwoju sytuacji na terenie miasta”, kolegium przyjęło w stosunku do obwinionych „ostrzejsze niż uprzednio kryteria” wymiaru kary. Rozpatrując sprawy w trybie postępowania przyspieszonego orzekano z reguły kary o charakterze izolacyjnym. Kolegium wymierzyło cztery kary aresztu zasadniczego (w wymiarze od 2 tygodni do 2 miesięcy) oraz osiem kar grzywny (od 800 do 3000 złotych) podlegających natychmiastowej zamianie na areszt zastępczy w razie ich nieuiszczenia na rozprawie. Kolegium odstępowało od

45 Ibidem.

46 Ibidem, 17.

47 Wśród zatrzymanych było 6 studentów UW oraz 3 Politechniki Warszawskiej, 5 pracowników uspołecznionych zakładów pracy, a jedna osoba nigdzie nie pracowała. Wiek 12 zatrzymanych wahał się w granicach 18-25 lat, 3 pozostali mieli odpowiednio 29, 33 i 48 lat. Informacja nr 2/68 z przebiegu rozpraw karno-administracyjnych przeciwko uczestnikom zajść na terenie Uniwersytetu Warszawskiego i niektórych ulic w dniu 8 marca 1968 r., IPN BU 1585/6657, 18. 
wymierzania kar wolnościowych tylko wtedy, gdy ,,z okoliczności sprawy, a zwłaszcza zachowania obwinionego na rozprawie, wynikało, że nie dojdzie do jego dalszego udziału w zajściach”. Do aresztu nie trafili jedynie ci zatrzymani, którzy podczas rozprawy wykazali skruchę, płakali lub w stosunku do których obecna na rozprawie rodzina zapewniła, że nie „dopuści do wyjścia na ulicę”48.

Ponieważ obwinieni z reguły nie przyznawali się do popełnienia zarzucanych czynów, kolegium było zmuszone do udowodnienia im winy na podstawie sporządzonych przez milicjantów protokołów przesłuchania zatrzymanych oraz znajdujących się w aktach sprawy notatek służbowych. Odstępstwo od zasady bezpośredniości uzasadniano tym, że ,wskazani we wniosku o ukaranie jako świadkowie funkcjonariusze MO musieli brać udział w akcji i nie wszyscy stawili się na rozprawę". W przeciwieństwie do pierwszego dnia rozpraw przeciwko uczestnikom protestów studenckich stwierdzono zmianę postawy obwinionych, z których, ,żaden [...] nie pozował na bohatera”. Trzech spośród nich wykazało natomiast „lekceważący stosunek do Kolegium i mającego zapaść orzeczenia skazującego", co skutkowało wymierzeniem im kar o charakterze wolnościowym. Pierwszym był 21-letni student II roku Filologii Orientalnej UW Andrzej A., który zdaniem kolegium w sposób arogancki „oświadczył na wstępie rozprawy, że przyznaje się do wszystkich zarzutów, że wszystko jest prawdą, i zapytał, gdzie ma zapłacić 3000 zł grzywny”. Skruchę miał okazać dopiero wtedy, gdy „kolegium po wnikliwym rozpatrzeniu jego sprawy wymierzyło 2 miesiące bezwzględnego aresztu". Lekceważąca postawa miała także cechować studenta V roku filologii rosyjskiej Andrzeja L., który ponadto „powoływał się na koneksje z Ministrem Wieczorkiem ${ }^{49}$ ". Dopiero podczas zadawania pytań przez przewodniczącego składu orzekającego obwiniony przestał ,zachowywać się bardzo pewnie" i okazał skruchę. Zapewnił, że nie będzie więcej brał udziału w manifestacjach i poprosił o ukaranie grzywną niepodlegającą zamianie na areszt zastępczy. Jednakże jego zachowanie w początkowej fazie rozprawy przesądziło o wymierzeniu mu kary dwóch tygodni aresztu zasadniczego. Trzecim z doprowadzonych do kolegium w dniu 11 marca 1968 r., który „,na rozprawie zachowywał się nonszalancko”, był nigdzie niepracujący 18-letni Tomasz L. Ten „młodzieniec z włosami spadającymi na ramiona" odmówił podpisania protokołu wyjaśnień złożonych przez niego na rozprawie. Jego postawa skłoniła członków składu orzekającego kolegium do wymierzeniu kary grzywny w maksymalnej wysokości 3000 złotych, podlegającej natychmiastowej zamianie na 60 dni aresztu zastępczego ${ }^{50}$.

Kolegium nie zawahało się przed ukaraniem aresztem zasadniczym obwinionego 22-letniego studenta Elektroniki Politechniki Warszawskiej Tomasza G., który według wniosku o ukaranie miał się wykazywać ,szczególną aktywnością we wznoszeniu okrzyków, w stawianiu biernego oporu zaprowadzającym porządek funkcjonariuszom MO”. Kiedy podczas rozprawy obwiniony „zaczął omdlewać”, obecni na rozprawie rodzice (ojciec - kierownik Biblioteki Instytutu Sztuki; matka - z zawodu nauczycielka) „podnieśli, że syn przeszedł wstrząs mózgu i musi iść do szpitala”. Kolegium zarządziło

48 Ibidem.

49 Chodziło o Janusza Wieczorka, który w latach 1956-1980 pełnił funkcję Szefa Urzędu Rady Ministrów.

50 Informacja $\mathrm{nr} 2 / 68 \mathrm{z}$ przebiegu rozpraw karno-administracyjnych przeciwko uczestnikom zajść w dniu 9 III 1968 r. IPN BU 1585/6657, 19-20. 
zbadanie stanu zdrowia obwinionego przez specjalnie w tym celu sprowadzonego lekarza służby zdrowia resortu spraw wewnętrznych. Lekarz potwierdził przypuszczenie członków składu orzekającego o symulowaniu przez obwinionego choroby, co skutkowało wymierzeniem kary sześciu tygodni aresztu zasadniczego ${ }^{51}$.

Osadzenia w areszcie uniknął zatrzymany 48-letni radiooficer statku „Bydgoszcz” Stanisław K., w którego sprawie kolegium wyjątkowo dysponowało dowodem w postaci zeznań występującego w roli świadka funkcjonariusza MO. Na rozprawie świadek potwierdził zawarte we wniosku o ukaranie zarzuty udziału obwinionego w stanie nietrzeźwym w zbiegowisku i wznoszenia w kierunku interweniujących milicjantów okrzyków „gestapo”. Obwiniony nie przyznał się do winy, twierdząc, że „po ukończeniu kursu radarzystów wypił sobie z kolegą i idąc na dworzec zaplątał się w zbiegowisko". Kolegium nie dało wiary tym wyjaśnieniom i ukarało Stanisława K. grzywną w wymiarze 3000 złotych z zamianą na 75 dni aresztu zastępczego. Jedynie z uwagi na konieczność wypłynięcia ukaranego w rejs dalekomorski kolegium odstąpiło od opatrzenia orzeczonej grzywny rygorem natychmiastowej wykonalności. Znacznie bardziej dotkliwe niż grzywna konsekwencje dla ukaranego mogły wyniknąć z faktu, że poinformowany o jego sprawie DSA MSW ,porozumiał się z właściwą służbą MW - wnioskując, aby spowodować odebranie ukaranemu, który w funkcjonariuszach MO widzi gestapo, prawo wyjazdu za granicę"52.

Niezależnie od wymierzonych kar dodatkową dolegliwością w stosunku do obwinionych zatrudnionych $\mathrm{w}$ sektorze uspołecznionym było powiadomienie kierownictwa ich zakładów pracy o fakcie ukarania. W zawiadomieniach wskazano nie tylko wysokość orzeczonej kary, lecz także charakter wykroczenia oraz okoliczności jego popełnienia. Ponadto na wniosek DSA MSW Urząd Spraw Wewnętrznych Prezydium Rady Narodowej m.st. Warszawy „zawiadomił pisemnie Ministra Oświaty i Szkolnictwa Wyższego o nazwiskach ukaranych w dniu 9.III. 1968 r. studentów Uniwersytetu Warszawskiego" 53 .

Ze względu na fakt posiadania wiarygodnych informacji o możliwości wybuchu protestów studenckich w innych niż Warszawa ośrodkach akademickich, w dniu 11 marca 1968 r. kierownictwo MSW podjęło decyzję o ustanowieniu specjalnych dyżurów w urzędach spraw wewnętrznych w Lublinie, Łodzi, Krakowie i Wrocławiu. W celu sprawnego przeprowadzenia rozpraw przeciwko sprawcom zakłóceń porządku publicznego podczas spodziewanych demonstracji studenckich przygotowano specjalne składy orzekające kolegiów. Tego dnia protesty studenckie na znak solidarności ze studentami warszawskim miały miejsce jedynie w Lublinie, gdzie organy MO „zatrzymały 48 osób, w tym 21 osób z Katolickiego Uniwersytetu Lubelskiego". Celem przeprowadzenia zaplanowanych na kolejny dzień rozpraw przed kolegium $\mathrm{w}$ trybie postępowania przyspieszonego, Urząd Spraw Wewnętrznych w Lublinie zwrócił się z pilną prośbą o podjęcie stosownej uchwały przez Prezydium Wojewódzkiej Rady Narodowej. Uchwała o wprowadzeniu postępowania przyśpieszonego w sprawach o wykroczenia polegające na zakłóceniu spokoju i porządku publicznego na terenie miasta Lublina została opublikowana w wydrukowanym w nocy z 11 na 12 marca Dzienniku Urzędowym Województwa

\footnotetext{
51 Ibidem, 20.

52 Ibidem.

53 Ibidem.
} 
Lubelskiego. Potrzeby tworzenia specjalnych składów orzekających kolegium nie było natomiast w Krakowie, gdyż zebrani na Rynku Starego Miasta studenci w liczbie 180200 rozeszli się na wezwanie funkcjonariuszy MO bez zakłócania porządku publiczne$\mathrm{go}^{54}$.

\section{Przebieg rozpraw karno-administracyjnych przeciwko zatrzymanym w dniu 11 marca $1968 \mathrm{r}$.}

Kulminacja rozpraw k-a przeciwko uczestnikom protestów studenckich na terenie Warszawy miała miejsce w dniu 13 marca. Tego dnia przed kolegiami postawiono 53 osoby (w tym 3 kobiety) zatrzymane przez MO w dniu 11 marca w związku z udziałem w demonstracjach ulicznych na terenie śródmieścia Warszawy. Spośród obwinionych o zakłócanie spokoju publicznego było tylko 13 studentów ${ }^{55}, 7$ uczniów ${ }^{56}, 22$ pracowników fizycznych, 8 inteligentów pracujących oraz 3 osoby nigdzie niepracujące ${ }^{57}$. Zdaniem DSA MSW niewielki odsetek studentów w grupie osób pociągniętych do odpowiedzialności k-a świadczył o stopniowym przekształcaniu się protestów w zamieszki o charakterze chuligańskim. Wśród osób doprowadzonych przed kolegium przeważali bowiem „drobni awanturnicy, którzy korzystając z chwilowego zamieszania włączali się do skupisk zakłócających spokój”. Ponadto dużą część zatrzymanych stanowili młodzi ludzie, którzy nie tyle popierali protestujących studentów, co ,z ciekawości i przekory brali udział w zbiegowiskach i mimo nawoływania MO nie rozchodzili się" 58 .

Sprawy osób obwinionych o zakłócanie porządku publicznego w dniu 13 marca 1968 r. w trybie przyspieszonym rozpatrywało 10 specjalnie utworzonych składów orzekających Kolegium Karno-Administracyjnego przy Prezydium Dzielnicowej Rady Narodowej Warszawa-Śródmieście. Łącznie w pracach kolegium tego dnia brało udział 40 osób reprezentujących ,aktyw robotniczy” warszawskich zakładów pracy. W ocenie DSA MSW poszczególne składy orzekające ,wykazały właściwą postawę i zrozumienie oraz dużą ofiarność", wykonując swoje obowiązki od 10 rano do 2 w nocy. Pomimo przeciągnięcia rozpraw do późnych godzin nocnych, ,żaden z członków Kolegium i personelu obsługującego nie starał się zwolnić”. Jednakże niektórzy z nich byli zdania, że „rozpatrywanie spraw w nocy jest nie wskazane ze względu na negatywny wydźwięk, jaki to może mieć w społeczeństwie". DSA MSW przyznało im rację, tłumacząc fakt przeciągania się rozpraw do późnych godzin nocnych „,nagromadzeniem osób zatrzymanych,

\footnotetext{
54 Ibidem.

55 Sześcioro z nich studiowało na UW, sześcioro na Politechnice Warszawskiej, jeden był studentem Szkoły Głównej Gospodarstwa Wiejskiego.

56 Pięciu z nich było uczniami techników, a dwóch pobierało naukę w z zasadniczych szkołach zawodowych.

57 Większość z zatrzymanych (38 osób) stanowili ludzie młodzi, w wieku nieprzekraczającym 25 lat. $15 \mathrm{z}$ nich nie ukończyło 19. roku życia, 13 było w wieku od 20 do 21 lat, 10 osób miało od 22 do 25 lat. Jedynie pięcioro obwinionych było w wieku powyżej 30 lat.

58 Informacja nr 4 z przebiegu rozpraw karno-administracyjnych przeciwko uczestnikom zajść w dniu 11 marca 1968 r. IPN BU 1585/6657, 23.
} 
które uniemożliwiło służbie śledczej przygotowanie w porę akt spraw do kolegium”. Ten „niewątpliwy mankament” miała rekompensować jawność rozpraw odbywających się w gmachu rady narodowej, „,do którego każdy ma prawo wstępu”. W rozprawach miała uczestniczyć „,dość duża ilość rodziców osób zatrzymanych”, a przebieg spraw przeciwko studentom UW obserwował dziekan Wydziału Prawa prof. Bogusław Leśnodorski ${ }^{59}$.

Tego dnia kolegium ukarało 40 obwinionych. Sprawy pozostałych 13 zatrzymanych zostały przekazane do rozpatrzenia w późniejszym terminie w zwykłym trybie postępowania k-a ze względu na brak oczywistych dowodów winy oraz świadków zdarzenia. Rezygnując z natychmiastowego ukarania, kolegium brało pod uwage ,postawę obwinionego na rozprawie i jego dotychczasowy tryb życia”, które sugerowały, że „nie weźmie on udziału w ewentualnych przyszłych zajściach".

Podczas rozpraw odbywających się 13 marca 1968 r. obwinieni „,nie przyznawali się do czynnej postawy, wznoszenia okrzyków", lecz przyjmując spokojną postawę wskazywali na fakt przypadkowego udziału w demonstracjach ulicznych. Kolegium „nie dawało wiary pokrętnym na ogół wyjaśnieniom" obwinionych, dążąc do ukarania zatrzymanych uczestników zamieszek nawet w sytuacji braku dostatecznych dowodów winy. W odniesieniu do większości zatrzymanych składy orzekające napotkały duże trudności z udowodnieniem winy, gdyż „na rozprawach nie było naocznych świadków, dokumentacja wniosków była niewłaściwa, a w tych sprawach, gdzie byli świadkowie, to byli nimi przeważnie kierowcy radiowozów, do których doprowadzano osoby zatrzymane, a nie funkcjonariusze, którzy bezpośrednio przeprowadzali interwencję". Pomimo występujących w aktach sprawy sprzeczności i braku świadków potwierdzających winę zatrzymanego kolegium wydawało orzeczenia o ukaraniuna podstawie zawartego we wniosku o ukaranie stwierdzenia, że ,obwiniony uczestniczył w zbiegowisku i pomimo wezwania nie opuścił go" ${ }^{\circ 0}$.

Kary wymierzone przez kolegium cechowała duża surowość, gdyż równo połowę z nich stanowiły kary aresztu zasadniczego. Pozostałych 20 obwinionych ukarano grzywną, która tylko w jednym przypadku nie podlegała zamianie na areszt zastępczy. Wobec ośmiu ukaranych aresztem zastępczym zastosowano rygor natychmiastowej wykonalności orzeczonej kary, wskutek czego prosto z sali rozpraw do aresztu odprowadzono 28 ukaranych (20 aresztem zasadniczym i 8 aresztem zastępczym). Jednym z dwóch ukaranych aresztem zasadniczym w maksymalnym wymiarze dwóch miesięcy był 20-letni student I roku Ekonomii Politycznej UW Abraham N. Został zatrzymany w związku z udziałem w manifestacji na Krakowskim Przedmieściu, podczas której miał się wyróżniać szczególną aktywnością we wznoszeniu okrzyków „Precz z komunizmem, precz z gestapowcami!’. Uzasadniając orzeczenie najsurowszej z możliwych kar, kolegium podkreślało fakt, że ukarany swoją postawą ,pobudzał do aktywności innych uczestników zajścia"61. Wprawdzie nie było o tym wzmianki w raporcie DSA MSW, lecz należy przypuszczać, że kolegium wzięło pod uwagę także imię ukaranego, które wyraźnie wskazywało na jego żydowskie pochodzenie.

Aresztem zasadniczym w wymiarze sześciu tygodni ukarany został uczestniczący w manifestacji pod pomnikiem Kopernika na Krakowskim Przedmieściu 24-letni stu-

59 Ibidem, 26.

60 Ibidem, 24

61 Ibidem, 25.

Artykuły - Articles 
dent V roku Geologii UW Wiesław F. Z wniosku o ukaranie wynikało, że znajdował się on w grupie osób wznoszącej pod adresem MO wrogie okrzyki, ,a następnie pomimo zakazu przedarł się przez kordon MO i zaczął uciekać”. Po zatrzymaniu „szarpał się z członkami ORMO”. Bardzo łagodnie na tle pozostałych zatrzymanych kolegium potraktowało 22-letniego Jacka K., z zawodu posadzkarza. Został on ukarany grzywną w wysokości 400 złotych z zamianą na 16 dni aresztu (bez rygoru natychmiastowej wykonalności) za sam fakt biernego udziału „w zbiegowisku na Placu Zbawiciela”. Orzekając łagodną karę, kolegium wzięło pod uwagę fakt, że „obwiniony jest inwalidą, a także jego trudne warunki materialne"62.

Oprócz kolegium warszawskiego sprawy przeciwko studentom obwinionym o zakłócanie spokoju publicznego w trybie postepowania przyspieszonego rozpatrywało także Kolegium Karno-Administracyjne przy Prezydium Miejskiej Rady Narodowej w Lublinie. W dniach 12 i 13 marca przed kolegium odpowiadało „23 zatrzymanych w związku z zajściami w dniu 11 marca"63, wobec których orzeczono trzy kary aresztu zasadniczego w maksymalnej wysokości dwóch miesięcy oraz 20 grzywien (w tym 9 w maksymalnej wysokości 3000 złotych). Wszystkie wymierzone grzywy podlegały zamianie na areszt zastępczy, aczkolwiek nie zostały opatrzone rygorem natychmiastowej wykonalności. 12 orzeczeń o ukaraniu grzywną zostało zaskarżonych na niekorzyść obwinionych przez oskarżyciela publicznego, który żądał podwyższenia przez kolegium II instancji zbyt łagodnych jego zdaniem kar. Były to kary wymierzone przez kolegium w dniu 12 marca zgodnie z ,dyrektywą władz wojewódzkich, ażeby wymierzać wyłącznie kary grzywny”. W wyniku interwencji podjętej przez Wojewódzki Urząd Spraw Wewnętrznych „w drugim dniu kary zostały zaostrzone”, o czym świadczy orzeczenie z 13 marca 1968 r. trzech kar aresztu zasadniczego i wysokich grzywien podlegających zamianie na areszt zastępczy ${ }^{64}$.

Do karania uczestników protestów studenckich stosowne przygotowania poczyniły organy administracji spraw wewnętrznych w Krakowie, z których inspiracji Prezydium Miejskiej Rady Narodowej podjęło uchwałę o wprowadzeniu od 13 marca przyspieszonego trybu postępowania k-a. Chociaż do krakowskich kolegiów nie wpłynęły wnioski o ukaranie za zakłócenia spokoju publicznego, w trakcie przygotowania przez funkcjonariuszy Komendy Miejskiej MO znajdowały się 24 wnioski „dotyczące zrywania afiszów wydrukowanych na polecenie władz". Zerwane afisze zawierały teksty artykułów wydrukowanych w prasie „w sprawie zajść w Warszawie"65.

62 Ibidem.

63 Wśród nich był ksiądz, 14 studentów KUL, 7 studentów UMCS i student akademii medycznej. Zatrzymano 18 mężczyzn i 5 kobiet, spośród których jedynie trzy osoby miały więcej niż 23 lata.

64 Ibidem, 27.

65 Ibidem. 


\section{Zakończenie}

Według informacji Generalnej Prokuratury z 6 czerwca 1968 r. w związku z wydarzeniami marcowymi przed kolegiami postawiono blisko 700 osób, w tym 143 studentów ${ }^{66}$. Jako pierwszych do odpowiedzialności k-a pociągnięto studentów protestujących w dniu 30 stycznia 1968 r. przeciwko decyzji władz o zawieszeniu wystawiania sztuki Dziady na scenie Teatru Narodowego. Dziewięcioro zatrzymanych przez MO uczestników manifestacji studenckiej pod pomnikiem Adama Mickiewicza na Krakowskim Przedmieściu zostało ukaranych przez Kolegium przy Prezydium DRN Warszawa-Śródmieście grzywną w zwyczajnym trybie postępowania ${ }^{67}$. Zapoczątkowane manifestacją w dniu 30 stycznia 1968 r. protesty studentów warszawskich uczelni osiągnęły swoje apogeum podczas wydarzeń marcowych w dniach 8-11 marca. Tym razem aparat spraw wewnętrznych był odpowiednio przygotowany do karania zatrzymanych przez MO uczestników protestów, o czym świadczy wprowadzenie na terenie Warszawy przyspieszonego trybu postępowania k-a w sprawach o zakłócenie spokoju publicznego. Świadczy o tym wyznaczenie specjalnych składów orzekających oraz czuwanie przez sprawujący obsługę organizacyjnoprawną kolegium Wydział Karno-Administracyjny Prezydium DRN Warszawa-Śródmieście nad „,prawidłowym przebiegiem rozpraw”, czyli orzekaniem surowych kar zgodnie z zaleceniami kierownictwa MSW. Skrupulatnej realizacji tych zaleceń sprzyjało zastosowanie przyspieszonego trybu postępowania, w ramach którego wzgląd na szybkość postępowania znacząco ograniczał przysługujące obwinionemu prawo do obrony. Zatrzymany na gorącym uczynku i niezwłocznie doprowadzony przed kolegium sprawca wykroczenia nie miał możliwości wybrania sobie obrońcy, chociaż u.k.a. przewidywała udział adwokatów w sprawach o wykroczenia zagrożone karą aresztu zasadniczego ${ }^{68}$. Postrzeganie uczestników wydarzeń marcowych w kategoriach przeciwników politycznych władzy komunistycznej znalazło swój wyraz w towarzyszącej kolegiom niechęci do ustalenia prawdy obiektywnej i dążeniu do ukarania zatrzymanych nawet pomimo braku dostatecznych dowodów ich winy. W sporządzonych przez DSA MSW sprawozdaniach brakuje bowiem jakiejkolwiek wzmianki o występowaniu świadków obrony w sprawach rozpoznawanych w trybie postępowania przyspieszonego. Jedynie w pierwszym dniu rozpraw orzeczenia o ukaraniu były wydane na podstawie zeznań występujących w charakterze świadków oskarżenia funkcjonariuszy MO, którzy brali udział w zatrzymaniu obwinionych. W kolejnych dniach punktem wyjścia ukarań były z reguły notatki służbowe sporządzone przez funkcjonariuszy MO, a w przypadku ich braku kolegium wymierzało kary, opierając się na zawartym we wnioskach o ukaranie stwierdzeniu, że obwiniony ,uczestniczył w zbiegowisku i pomimo wezwania nie opuścił go".

66 Kamiński, Represje.

67 Notatka w sprawie zastosowania represji karno-administracyjnej wobec niektórych uczestników zajścia w dniu 30 stycznia 1968 r. w okolicach Teatru Narodowego. Dąbrowski, Gontarczyk, Tomasik, Marzec 1968 w dokumentach MSW. T. 2, Kronika wydarzeń, cz. I, 9-12.

68 Notatka w zakresie stosowania kary aresztu przez kolegia przy prezydiach rad narodowych wg założeń projektu noweli do ustawy z dnia 15 grudnia 1951 r. o orzecznictwie k.a., IPN BU MSW 1585/6439, s. 414-5.

Artykuły - Articles 
Kary wymierzane uczestnikom wydarzeń marcowych cechowała surowość, która wynikała z faktu orzekania w pierwszej kolejności kar o charakterze izolacyjnym aresztu zasadniczego i wysokich grzywien podlegających zamianie na areszt zastępczy. Dolegliwość kar wzmacniało ich orzekanie w przewidującym natychmiastową wykonalność orzeczeń trybie postępowania przyspieszonego, co skutkowało osadzeniem w areszcie ukaranych grzywną wskutek niemożności opłacenia kary na rozprawie przed kolegium. Represyjność kar wymierzonych w uczestników wydarzeń marcowych znajdzie swój wyraz w sporządzonym przez DSA MSW sprawozdaniu z przebiegu orzecznictwa k-a w 1968 r. Odnotowane w nim zwiększenie liczby kar aresztu zasadniczego i zastępczego w porównaniu z rokiem poprzednim „,nastąpiło na skutek zakłóceń spokoju publicznego w marcu b.r." ${ }^{\prime 69}$. Zapoczątkowana podczas wydarzeń marcowych $1968 \mathrm{r}$. polityka surowego karania uczestników protestów społecznych będzie kontynuowana przez w pełni dyspozycyjne wobec MSW kolegia w latach osiemdziesiątych ${ }^{70}$, zwłaszcza podczas obowiązywania stanu wojennego ${ }^{71}$. Odejście od praktyki nadużywania trybu postępowania przyspieszonego celem represjonowania opozycji politycznej nastąpi dopiero na fali przemian społeczno-politycznych roku 1989 r. i w pierwszej kolejności znajdzie swój wyraz w zniesieniu natychmiastowej wykonalności zapadłych w tym trybie orzeczeń ${ }^{72}$.

\section{Bibliografia}

\section{Źródła archiwalne}

Instytut Pamięci Narodowej, zespół akt Ministerstwo Spraw Wewnętrznych, sygn. teczek IPN BU 1584/524, IPN BU MSW 1584/6504, IPN BU MSW 1585/1919, IPN BU MSW 1585/6439, IPN BU 1585/6657.

\section{Źródła drukowane}

Dąbrowski, Franciszek, Gontarczyk, Piotr i Tomasik, Paweł, red. nauk. Marzec 1968 r. $w$ dokumentach MSW. T. 2: Kronika wydarzeń, cz. 1, oprac. Piotr Byszewski [et al.]. Warszawa: Instytut Pamięci Narodowej - Komisja Ścigania Zbrodni przeciwko Narodowi Polskiemu, 2009.

69 O ile w 1967 r. karę aresztu zasadniczego i zastępczego odbyło 14449 osób, o tyle w roku wydarzeń marcowych w areszcie przebywało 16615 sprawców wykroczeń. Orzecznictwo karno-administracyjne w 1968 r. Informacja DSA MSW z dnia 18 lutego 1969 r. IPN BU MSW 1584/6504, 143.

70 Kolegia ds. wykroczeń w PRL, 18.

71 Szerzej na ten temat Łysko, „Działalność kolegiów”, 83-99.

72 Ustawa z dnia 29 maja 1989 r. o zmianie niektórych przepisów prawa karnego, prawa o wykroczeniach oraz innych ustaw (Dz.U. $1989 \mathrm{nr} 34$ poz. 180). 


\section{Źródła prawa}

Rozporządzenie Prezydenta Rzeczypospolitej Polskiej z dnia 11 lipca 1932 r. Prawo o wykroczeniach (Dz.U. $1932 \mathrm{nr} 60$ poz. 572).

Ustawa z dnia 15 grudnia 1951 r. o orzecznictwie karno-administracyjnym (Dz.U. $1951 \mathrm{nr} 66$ poz. 454).

Dekret z dnia 7 grudnia 1954 r. o naczelnych organach administracji państwowej w zakresie spraw wewnętrznych i bezpieczeństwa publicznego (Dz.U. $1954 \mathrm{nr} 54$ poz. 269).

Ustawa z dnia 25 stycznia 1958 r. o radach narodowych (Dz.U. $1958 \mathrm{nr} 5$ poz. 16).

Ustawa z dnia 22 maja 1958 r. o zaostrzeniu odpowiedzialności karnej za chuligaństwo (Dz.U. $1958 \mathrm{nr} 34$ poz. 152).

Ustawa z dnia 2 grudnia 1958 r. o zmianie ustawy z dnia 15 grudnia 1951 r. o orzecznictwie karno-administracyjnym (Dz.U.1958 nr 77 poz. 396).

Ustawa z dnia 10 grudnia 1959 r. o zwalczaniu alkoholizmu (Dz.U. $1959 \mathrm{nr} 69$ poz. 434).

Ustawa z dnia 17 czerwca 1966 r. o przekazaniu niektórych drobnych przestępstw jako wykroczeń do orzecznictwa karno-administracyjnego (Dz.U. 1966 nr 23 poz. 149).

Ustawa z dnia 20 maja 1971 r. Kodeks wykroczeń (Dz.U. 1971 nr 12 poz. 114).

Ustawa z dnia 20 maja 1971 r. Kodeks postępowania w sprawach o wykroczenia (Dz.U. 1971 nr 12 poz. 116).

Ustawa z dnia 20 maja 1971 r. Przepisy wprowadzające Kodeks postępowania w sprawach o wykroczenia (Dz.U. $1971 \mathrm{nr} 12$ poz. 117).

Ustawa z dnia 20 maja 1971 r. o ustroju kolegiów do spraw wykroczeń (Dz.U. 1971 nr 12 poz. 118).

Ustawa z dnia 29 maja 1989 r. o zmianie niektórych przepisów prawa karnego, prawa o wykroczeniach oraz innych ustaw (Dz.U. $1989 \mathrm{nr} 34$ poz. 180).

\section{Opracowania}

Bafia, Jerzy. O zaostrzeniu i przyśpieszeniu odpowiedzialności karnej za chuligaństwo. Komentarz do Ustawy z dn. 22 V 1958 r. o zaostrzeniu odpowiedzialności karnej za chuligaństwo oraz do przepisów związkowych. Warszawa: Wydawnictwo Prawnicze, 1959.

Chmielewski, Henryk. ,, Nowe poważne zadania”. Poradnik dla Kolegiów Orzekających 3 (1958): $1-10$.

Eisler, Jerzy. Marzec 1968. Warszawa: Wydawnictwo Instytutu Pamięci Narodowej, 2006. Eisler, Jerzy. Polski rok 1968. Warszawa: Instytut Pamięci Narodowej - Komisja Ścigania Zbrodni Przeciwko Narodowi Polskiemu, 2006.

Gubiński, Arnold. „Areszt zasadniczy i zastępczy”. Zagadnienia Karno-Administracyjne 6 (1963): 53-62.

Gubiński, Arnold. „Ewolucja stosowanych przez kolegia środków karnych i zasad wymiaru kary”. Zagadnienia Wykroczeń 6 (1977): 24-42.

Autor nieznany. „Karanie wykroczeń chuligańskich”. Zagadnienia Karno-Administracyjne 1 (1964): 1-6.

Kolegia ds. wykroczeń w PRL (rozwiązania ustawowe i praktyka). Broszura opracowana i wydana staraniem Komisji Interwencji i Praworządności NSZZ „Solidarność” oraz Małopolskiego Komitetu Walki o Praworządność. Warszawa-Kraków: 1987.

Kamiński, Łukasz. Represje. https://marzec1968.pl/m68/historia/6965,Represje.html (data pobrania: 8.01.2020).

Lewiński, Janusz. „Kształtowanie stosowanej przez kolegia do spraw wykroczeń polityki kara- 
nia przez organy nadzoru". W: Materiały na Sesję Popularno-Naukową z okazji XXV-lecia kolegiów do spraw wykroczeń (21 IV 1977 Warszawa), wydane przez DSA MSW we współpracy z Akademią Spraw Wewnętrznych im. Feliksa Dierżyńskiego, red. Jan Smereczański, Warszawa: 1977.

Leoński, Zbigniew. „Kolegia w systemie organów rady narodowej”. Zagadnienia Karno-Administracyjne 6 (1968): 12-22.

Łysko, Marcin. „Aparat biurokratyczny orzecznictwa karno-administracyjnego Polski Ludowej”. W: Dzieje biurokracji. T. 5, cz. 2, red. Andrzej Gaca, Artur Górak, Zbigniew Naworski, 561676. Włocławek [etc.]: Wydawnictwo Państwowej Wyższej Szkoły Zawodowej, 2013.

Łysko, Marcin. „Działalność kolegiów do spraw wykroczeń w okresie obowiązywania stanu wojennego". Studia Prawno-Ekonomiczne CXII (2019): 83-89.

Łysko, Marcin. „,Ewolucja polskiego systemu prawa wykroczeń w XX wieku”. Miscellanea Historico-Iuridica XVII, z. 1 (2018): 167-192.

Łysko, Marcin. „Kształtowanie polityki karnej w sprawach o wykroczenia przez aparat administracji Polski Ludowej". W: Dzieje biurokracji. T. 8: (2018), red. Tatjana Bykowa, Artur Górak, Jacek Legieć, 169-188. Lublin: Towarzystwo Nauki i Kultury „Libra”, 2018.

Łysko, Marcin, „Kształtowanie się ustroju kolegiów orzekających w Polsce Ludowej (19521956)". Czasopismo Prawno-Historyczne LXIV, z. 2 (2012): 249-275.

Łysko, Marcin. „Orzecznictwo karno-administracyjne w walce $\mathrm{z}$ alkoholizmem w okresie gomułkowskim". Z Dziejów Prawa 4 (2011): 249-279.

Łysko, Marcin. Prace nad kodyfikacja materialnego prawa wykroczeń w Polsce Ludowej (19601971). Białystok: Temida 2, 2016.

Łysko, Marcin. „Problem chuligaństwa w orzecznictwie karno-administracyjnym Polski Ludowej”. Czasopismo Prawno-Historyczne LX, z. 2 (2008): 79-202.

Łysko, Marcin. ,, Reforma prawa karno-administracyjnego Polski Ludowej z 1958 r.”. Z Dziejów Prawa 7 (2014): 211-242.

Łysko, Marcin. „Socjalistyczna reforma orzecznictwa karno-administracyjnego Polski Ludowej”. W: Księga pamiątkowa dla uczczenia pamięci Profesor Krystyny Kamińskiej, red. Andrzej Gaca, 315-344. Torun, Towarzystwo Naukowe Organizacji i Kierownictwa Dom Organizatora, 2013.

Łysko, Marcin. „Zasady obsady personalnej kolegiów karno-administracyjnych Polski Ludowej”. Miscellanea Historico-Iuridica XII (2013): 321-349.

Marzec 1968. W: Historia PRL, praca zbiorowa, T. 13: 1968 [aut. tekstów Ewa Krupnik et al.], seria: Wielka Kolekcja 1944-1989. Warszawa: New Media Concept. Axel Springer Polska, 2009.

Pacholarz, Elżbieta. „Wykroczenia «alkoholowe» (w świetle statystyki kolegiów)”. Zagadnienia Karno-Administracyjne 4 (1968): 18-27.

Przybysiak, Ireneusz, „Od «Biuletynu» do «Zagadnień Wykroczeń»”. Zagadnienia Wykroczeń 2 (1976): 22-27.

Siarkiewicz, Kazimierz. „Kształtowanie się ustroju kolegiów”. Zagadnienia Wykroczeń 4-5 (1977): 31-46. 